\title{
Critical limits for zinc to forage species
}

This study aimed to determine the critical limit (LC) of $\mathrm{Zn}$ for plants of Brachiaria Humidicola, Panicum maximum cultivars Aruana and Tanzania and Paspalum notatum cv. Pensacola, grown in a Cambisol fertilized with zinc sulfate. Methods: The experiment was realized in the municipality of Lages, Brazil. The experimental design was completely randomized, with four replications. The treatments consisted of applying doses of $\mathrm{Zn}(0,25,50$, and $75 \mathrm{mg} \mathrm{Kg}-1)$ to the soil and four forage species. Plant height, leaf length, leaf SPAD index, shoot dry mass (MSPA), $\mathrm{Zn}, \mathrm{Cu}, \mathrm{Ca}, \mathrm{Mg}, \mathrm{Fe}$, and P contents were analyzed and the LC was determined. Results: For Pensacola, a decrease of $79.63 \%$ was found for leaf length and an increase of $147.48 \%$ for MSPA. Aruana showed a reduction of $15.43 \%$ and $67.05 \%$ for MSPA and SPAD index, respectively. An interaction was observed between the doses of $\mathrm{Zn}$ and the leaf contents of Fe and $\mathrm{Zn}$ for Humidicola reaching $175.08 \%$ and $564.18 \%$ respectively. For Tanzania, in the leaf contents, there was an increase of $\mathrm{Zn}$ by $442.6 \%$ and a reduction by $\mathrm{Mg} 80.34 \%$. For Aruana, there was an increase in $\mathrm{Ca}$ and $\mathrm{Zn}$ by $127.07 \%$ and $422.22 \%$, respectively, and a reduction in Fe levels by $64.6 \%$. The LC observed for Aruana, Tanzania and Humidicola were $13.0 ; 9.1$ and $29.1 \mathrm{mg} \mathrm{Kg}-1$. Conclusion: Among the forage species, the Humidicola has the potential to be used in places with a zinc deficiency because it has the highest LC and the highest concentration of this micronutrient.

Keywords: Cambisol; Micronutrient; Fertilizer; Critic level; Forage grasses.

\section{Limites críticos para zinco para espécies forrageiras}

Este trabalho teve como objetivo determinar o limite crítico (LC) de Zn para plantas de Brachiaria Humidicola, Panicum maximum cultivares Aruana e Tanzânia e Paspalum notatum cv. Pensacola, cultivada em Cambissolo fertilizado com sulfato de zinco. Métodos: $\mathrm{O}$ experimento foi realizado no município de Lages, Brasil. $\mathrm{O}$ delineamento experimental foi inteiramente casualizado, com quatro repetições. Os tratamentos consistiram na aplicação de doses de $\mathrm{Zn}(0,25,50$ e 75 mg Kg-1) ao solo e quatro espécies forrageiras. Foram analisados ??os teores de altura de planta, comprimento de folha, índice SPAD foliar, massa seca da parte aérea (MSPA), Zn, Cu, Ca, Mg, Fe e P e determinada a LC. Resultados: Para Pensacola, uma diminuição de 79,63\% foi encontrada para o comprimento da folha e um aumento de 147,48\% para a MSPA. Aruana apresentou redução de 15,43\% e 67,05\% para os índices MSPA e SPAD, respectivamente. Foi observada interação entre as doses de $\mathrm{Zn}$ e os teores foliares de Fe e Zn para Humidicola atingindo 175,08\% e 564,18\% respectivamente. Para a Tanzânia, no conteúdo foliar, houve aumento de $\mathrm{Zn}$ em 442,6\% e redução de $\mathrm{Mg}$ em 80,34\%. Para Aruana, houve um aumento no Ca e Zn em 127,07\% e 422,22\%, respectivamente, e uma redução nos níveis de Fe em 64,6\%. O LC observado para Aruana, Tanzânia e Humidicola foi de 13,0; 9,1 e 29,1 mg Kg-1. Conclusão: Dentre as espécies forrageiras, a Humidicola tem potencial para ser utilizada em locais com deficiência de zinco por apresentar o maior CL e a maior concentração desse micronutriente.

Palavras-chave: Cambisol; Micronutriente; Fertilizante; Nível crítico; Gramíneas forrageiras.

\section{Topic: Ciências do Solo}

Reviewed anonymously in the process of blind peer.
Received: 08/06/2021

Approved: 24/06/2021
Andressa Pinto dos Santos

Universidade do Estado de Santa Catarina, Brasil http://lattes.cnpq.br/7757064336752835 http://orcid.org/0000-0002-2076-4716

andress19841@hotmail.com

Caroline Aparecida Matias

Universidade do Estado de Santa Catarina, Brasil http://lattes.cnpq.br/7110658114343015 carolineaparecidamatias@gmail.com

\section{Fernanda Cantoni (iD}

Universidade do Estado de Santa Catarina, Brasil

http://lattes.cnpq.br/3982668147965819

http://orcid.org/0000-0002-6574-4305

cantoni.f@hotmail.com

\author{
David José Miquelluti (iD \\ Universidade do Estado de Santa Catarina, Brasil \\ http://lattes.cnpq.br/0683203409889468 \\ http://orcid.org/0000-0002-7369-6163 \\ dmiquell@gmail.com \\ Mari Lucia Campos (iD \\ Universidade do Estado de Santa Catarina, Brasil \\ http://lattes.cnpq.br/4291057837136509 \\ http://orcid.org/0000-0003-3250-2067 \\ mari.campos@udesc.br
}

Referencing this:

SANTOS, A. P.; MATIAS, C. A.; CANTONI, F.; MIQUELLUTI, D. J.; CAMPOS, M. L.. Critical limits for zinc to forage species. Revista Ibero Americana de Ciências Ambientais, v.12, n.6, p.97-107, 2021. DOI: http://doi.org/10.6008/CBPC2179-6858.2021.006.0008 


\section{INTRODUCTION}

The main source of feed for cattle in Brazil comes mainly from pastures, consisting mainly of grasses. For formation and maintenance of pastures, it is important that the supply and balance of nutrients are adequate, directly influencing the quality of forage. The practice of fertilization is indispensable to obtain good productivity of pastures, especially micronutrients such as zinc (HERNANDES et al., 2009).

Zinc is essential for plant growth, being responsible for nutritional regulation, chlorophyll synthesis, reproductive growth, carbohydrate production and seed and fruit development (TRIPATHI et al., 2015). However, the presence of $\mathrm{Zn}$ in tropical soils, in a natural way, is scarce, with a deficiency of this micronutrient (FAQUIN, 2005), which has limited the production of agricultural crops in Brazil (PRADO et al., 2008), caused crop yield losses that can exceed 40\% (ALLOWAY, 2008; SADEGHZADEH, 2013).

In plants, $\mathrm{Zn}$ acts on protein synthesis and plant growth, participating in the formation of the amino acid tryptophan, which forms indole acetic acid, which is essential for apical growth and cell expansion. When a plant is deficient in zinc, it has reduced height, internodes, leaves and productivity (SANTOS et al., 2009a; MUNER et al., 2011).

Although there is no zinc deficiency in pastures, it is observed that the content of zinc in plant tissue in many forages tends to be lower than the minimum requirement for cattle (ALLOWAY, 2008), which is 30 $\mathrm{mg} \mathrm{kg}{ }^{-1} . \mathrm{Zn}$ of dry matter for beef cattle (NRC, 1996). Thus, it is recommended that when the $\mathrm{Zn}$ levels are below $20 \mathrm{mg} \mathrm{kg}^{-1}$, an inorganic (or organic) fertilization is carried out through foliar applications or in the $\mathrm{Zn}$ soil (CHATZISTATHIS, 2014).

The concept of toxic level or critical limit (LC) is related to the content of a certain nutrient in which there is a reduction in production based on the maximum level of productivity (FAGERIA et al., 1997). In general, the LC of an element can be correlated with parameters related to crop production, such as: photosynthesis, growth rate and dry mass production (MALAVOLTA et al., 1997). The toxicity level is reached when these parameters are reduced between 80 to $95 \%$ of the optimum production (BATAGLIA et al., 1992). Upon reaching toxicity, the concentration of the nutrient is higher than sufficiency, reaching the critical physiological level, exceeding the entire range of luxury consumption and causing negative effects on crop yields (KURIHARA et al., 2005). This study determined the LC of Zn for plants of Brachiaria humidicola, Panicum maximum cultivars Aruana and Tanzania and Paspalum notatum cv. Pensacola, grown in a Humic Cambisol fertilized with zinc sulphate.

\section{METHODOLOGY}

An experiment was conducted from February to May 2017, in a greenhouse, on the premises of the Department of Soils and Natural Resources of CAV/UDESC - Lages/SC. The soil used was a leptic Aluminium Humic Cambisol, collected at a depth of 0 to $20 \mathrm{~cm}$. The region has well-defined seasons, with average annual temperatures of 15 to $25 \stackrel{\circ}{ } \mathrm{C}$, average annual rainfall distribution of $1500 \mathrm{~mm}$, characterized by the climate type Cfb - Temperate (humid mesothermal and mild summer) by the Koeppen classification (EPAGRI). Two 
soil samples were sent to the Soil Chemical Analysis Laboratory - LASQ of CAV-UDESC, the average values being reported: $\mathrm{pH}$ in water 5.0; SMP index 4.8, CTC at pH 7.0 of $23.3 \mathrm{cmol}_{\mathrm{c}} \mathrm{dm}^{-3}$; base saturation of $25.8 \%$, contents of exchangeable $\mathrm{Al}, \mathrm{Ca}$ and $\mathrm{Mg} 2.75 ; 3.16$ and $2.55 \mathrm{cmol}_{\mathrm{c}} \mathrm{dm}^{-3}$ respectively; $\mathrm{K}, \mathrm{P}, \mathrm{Fe}$ and $\mathrm{Mn}$ contents of $122,3,55.4$ and $3.8 \mathrm{mg} \mathrm{dm}^{-3}$, respectively; and content of organic matter and clay of 25 and $400 \mathrm{~g} \mathrm{dm}^{-3} \%$, respectively. The $\mathrm{Zn}$ content was $0.3 \mathrm{mg} \mathrm{dm}^{-3}$, being below the critical level of $0.5 \mathrm{mg} \mathrm{dm}^{-3}$ (CQFS-RS/SC).

The $\mathrm{pH}$ correction was carried out with the addition of dolomitic lime, and during the incubation period the field capacity was maintained at $60 \%$. The $\mathrm{pH}$ stabilization at 5.9 occurred on the 30th day. After this period, $0.48 \mathrm{~g} \mathrm{~kg}^{-1}$ of urea were applied; $0.18 \mathrm{~g} \mathrm{~kg}^{-1}$ of potassium chloride and $0.5 \mathrm{~g} \mathrm{~kg}^{-1}$ of triple superphosphate, as recommended in the fertilization and liming manual (CQFS-RS/SC). Concomitantly, increasing doses of $\mathrm{Zn}$ were applied to the soil $\left(0,25,50\right.$ and $\left.75 \mathrm{mg} \mathrm{Kg}^{-1}\right)$, using zinc sulphate $\left(\mathrm{ZnSO}_{4} .7 \mathrm{H}_{2} \mathrm{O}\right)$.

The experimental design was completely randomized, with four replications. The treatments consisted of applying increasing doses of $\mathrm{Zn}\left(0,25,50\right.$ and $\left.75 \mathrm{mg} \mathrm{kg}^{-1}\right)$ to the soil and four forage species, namely: Panicum maximum Jacq. cultivars Aruana and Tanzania, Paspalum notatum Flügge cv. Pensacola and Brachiaria humidicola.

In each experimental unit, 15 seeds were sown. Thinning was carried out ten days after emergence, leaving two plants per pot. At 70 days after sowing, plant height, leaf length, SPAD index of leaves were determined using a portable chlorophyll meter (SPAD 502; Konica Minolta ${ }^{\circledR}$, Tokyo, Japan). The readings of the SPAD index were made in the middle third (SPADme) of three leaves.

The plants were harvested at 72 days, when growth stabilization occurred. The aerial part of the plant was dried in a forced air circulation oven, at $65^{\circ} \mathrm{C}$, for 72 hours.

For the extraction of $\mathrm{Zn}, \mathrm{Ca}, \mathrm{Cu}, \mathrm{Fe}, \mathrm{Mg}$ and $\mathrm{P}$ from the aerial part the acid digestion of the samples was carried out using the method 3051A in a Multiwave 3000 microwave oven (Anton Paar, Graz, Austria). After cooling, the samples were transferred to falcon tubes, with a volume of $25 \mathrm{~mL}$ with ultrapure water. The extraction and quantification were performed in duplicates. The levels of $\mathrm{Zn}, \mathrm{Cu}, \mathrm{Ca}, \mathrm{Mg}, \mathrm{Fe}$ and $\mathrm{P}$ were quantified by an inductively coupled plasma emission spectrometer (ICP-OES) (Optima ${ }^{\circledR} 8300$, Perkin Elmer, USA). The reliability of the analytical method used to determine the levels of $\mathrm{Zn}$ in plants was guaranteed by the use of standard reference material from the National Institute of Standards and Technology (NIST - SRM Pine Needles 1575a). The recovered levels of $Z n$ in the reference sample (NIST) were $84 \%$ of $Z n$.

To determine the LC of $\mathrm{Zn}$, the MSPA production data of the aerial part were used. The LC was calculated based on a $10 \%$ reduction in dry matter production after it reached its maximum level (Fageria et al. 1997). To find the toxic level, therefore, the calculation was performed based on the adjusted regression equation and with $y=90 \%$. Data were subjected to analysis of variance using the $F$ test, at $5 \%$ probability of error. The models were fitted into regression equations using the Sigma Plot 12.5 software.

\section{RESULTS}

There was an interaction between Pensacola and $\mathrm{Zn}$ levels in the soil for leaf length and MSPA, as shown in Figure 1. There was a linear decrease of $79.63 \%$ for leaf length and polynomial increase of $147.48 \%$ 
for MSPA, with a minimum of $47.48 \%$ found in the dose of $25 \mathrm{mg} \mathrm{kg}^{-1}$. There was no significant difference for the SPAD index (Table 1).

Table 1: Average values of parameters that did not show a significant difference.

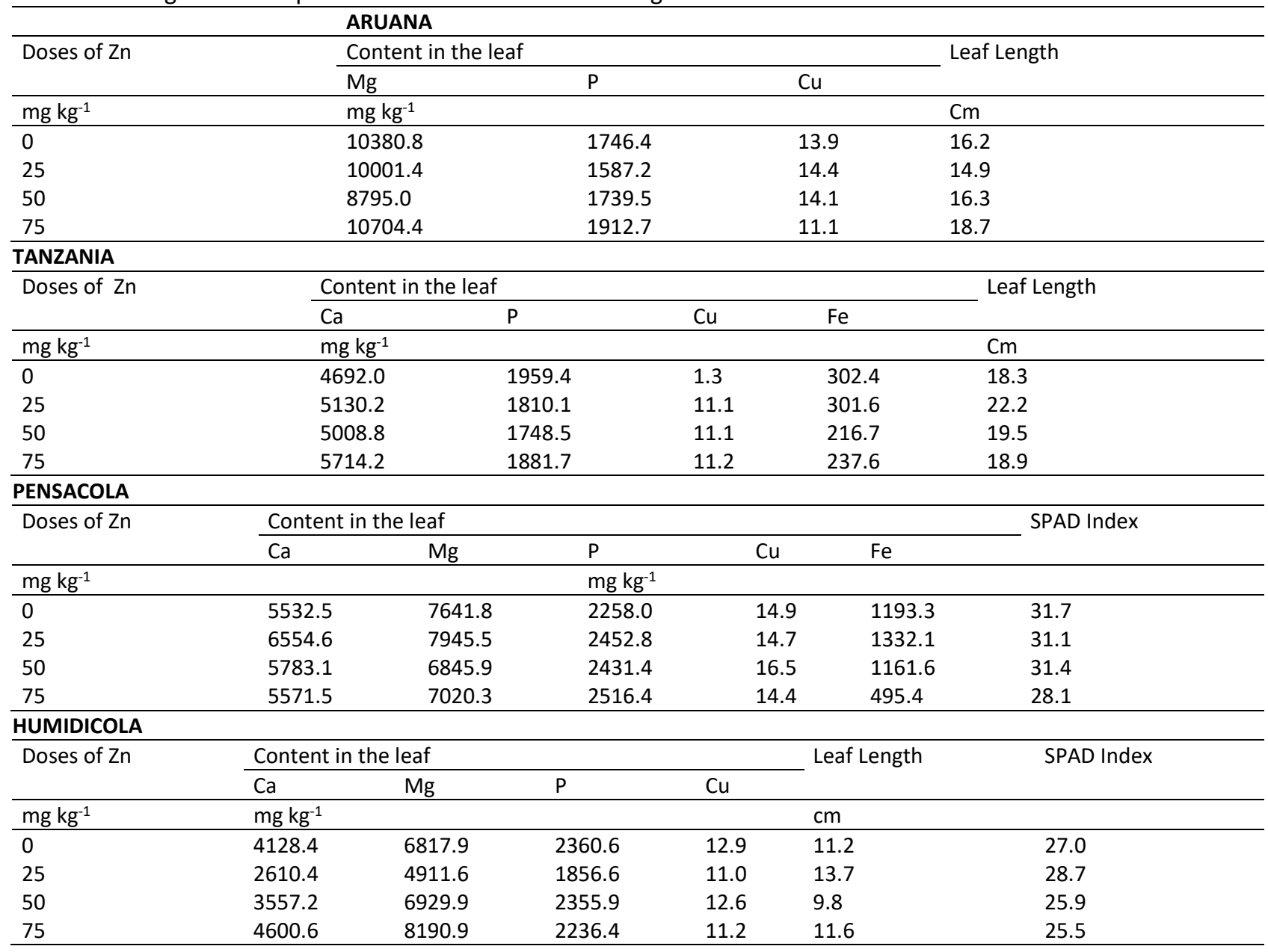
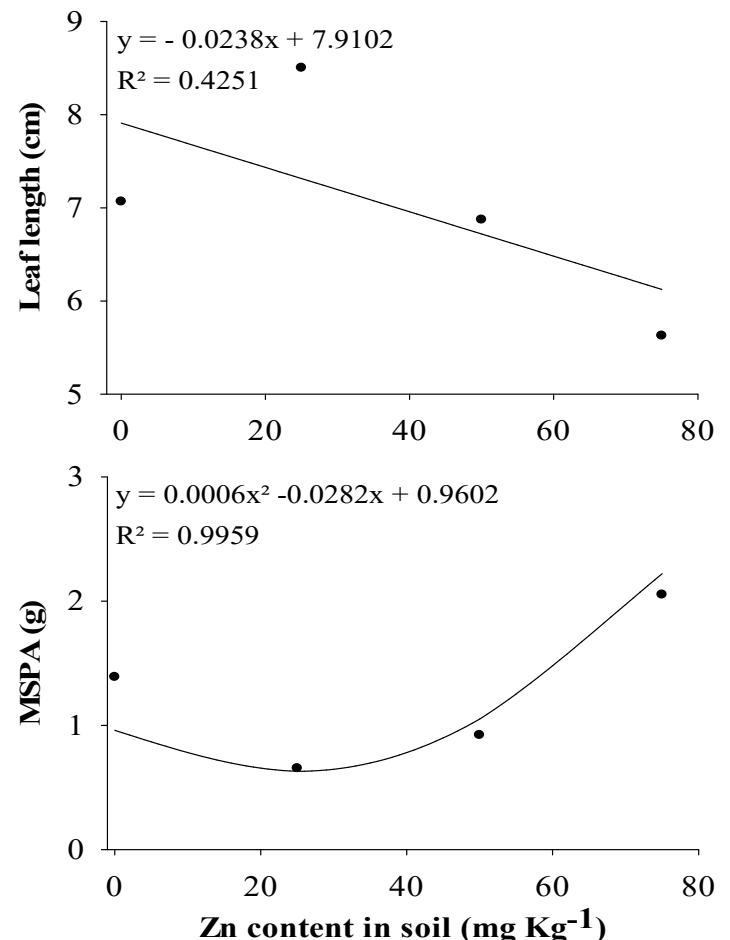

Fig. 1: Leaf length and dry mass of aerial part (MSPA) of Paspalum notatum Flügge cv. Pensacola subjected to different doses of $\mathrm{Zn}$ applied to the soil. 
There was an interaction between the doses of $\mathrm{Zn}$ and MSPA for Aruana (Figure 2) and, SPAD index for Aruana and Tanzania (Figure 3). For MSPA there was a linear reduction of $15.43 \%$. While for the SPAD index there was a linear decrease of $67.05 \%$ and $50.09 \%$ for Aruana and Tanzania respectively. There was no significant interaction for soil Zn and MSPA doses, leaf length and SPAD index for Brachiaria humidicola (Table 1).

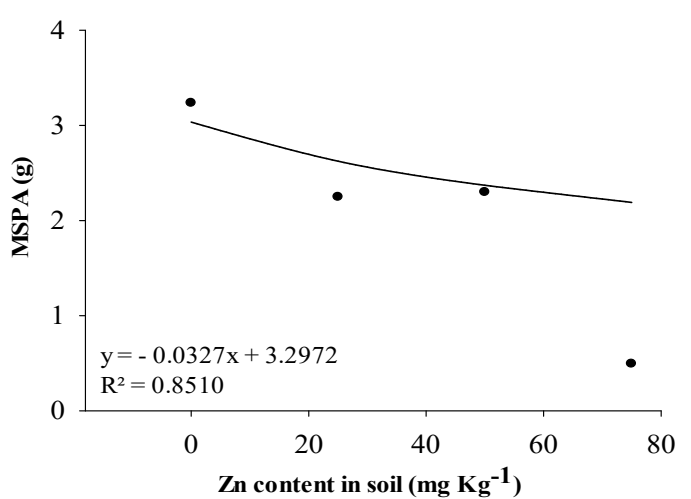

Fig. 2: Dry mass of the aerial part (MSPA) observed in Panicum maximum Jacq. cv. Aruana, subjected to increasing concentrations of $\mathrm{Zn}$.
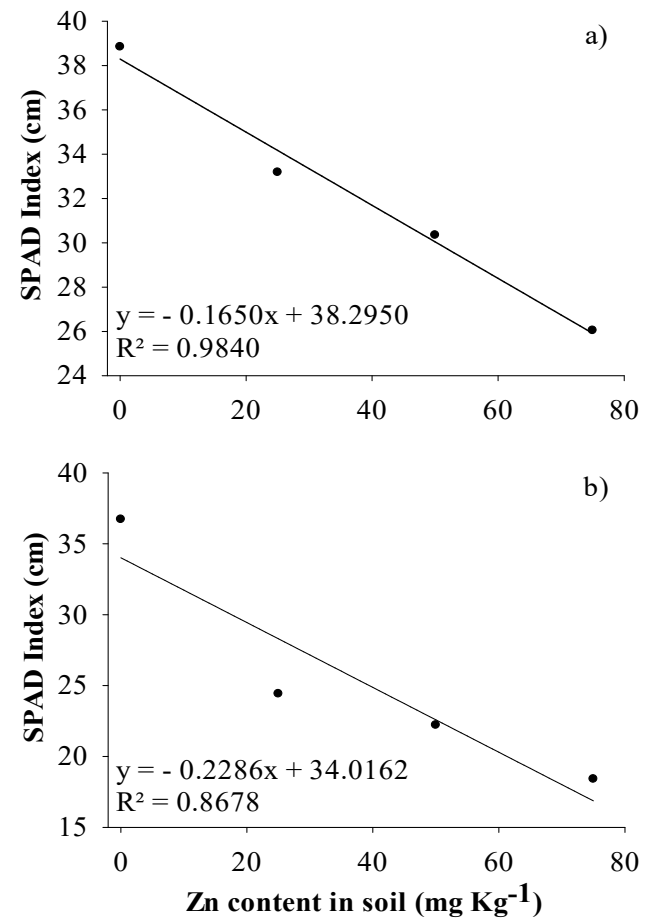

Fig. 3: SPAD index observed for Panicum maximum Jacq. cv. Aruana (a) and cv. Tanzania (b), subjected to increasing doses of $\mathrm{Zn}$ applied to the soil.

\section{Nutrient content in species}

The forage species showed a differential response to the nutrient content in the leaf when exposed to the $\mathrm{Zn}$ doses. For Aruana, there was a change in $\mathrm{Ca}$, $\mathrm{Fe}$ and $\mathrm{Zn}$ behaviour as shown in Figure 4. The increase in the concentration of the element linearly increased the levels of $\mathrm{Ca}$ in the leaf by $127.07 \%$. In addition, the regression of Fe and $\mathrm{Zn}$ levels showed a polynomial response with an increase of $\mathrm{Zn}$ by $422.22 \%$ and a reduction of $84.66 \%$ for $\mathrm{Fe}$, reaching a maximum reduction of $69.29 \%$ in the dose of $25 \mathrm{mg} \mathrm{kg}^{-1}$. There was no significant difference for $\mathrm{P}, \mathrm{Mg}$ and $\mathrm{Cu}$, as shown in Table 1.

There was an interaction between the doses of $\mathrm{Zn}$ and the leaf contents of Fe and $\mathrm{Zn}$ for humid crops, reaching $175.08 \%$ and $564.18 \%$ respectively, as shown in Figure 5 . For the other nutrients there was no significant interaction (Table 1).

The increase in the concentration of $\mathrm{Zn}$ did not significantly differ the levels of $\mathrm{Ca}, \mathrm{P}, \mathrm{Cu}$ and $\mathrm{Fe}$, for Tanzania, as shown in Table 1. However, it provided a linear increase for the leaf content of $\mathrm{Zn}$ in $442.60 \%$ and reduction for the leaf content of $\mathrm{Mg}$ by $80.34 \%$, as shown in Figure 6 . 

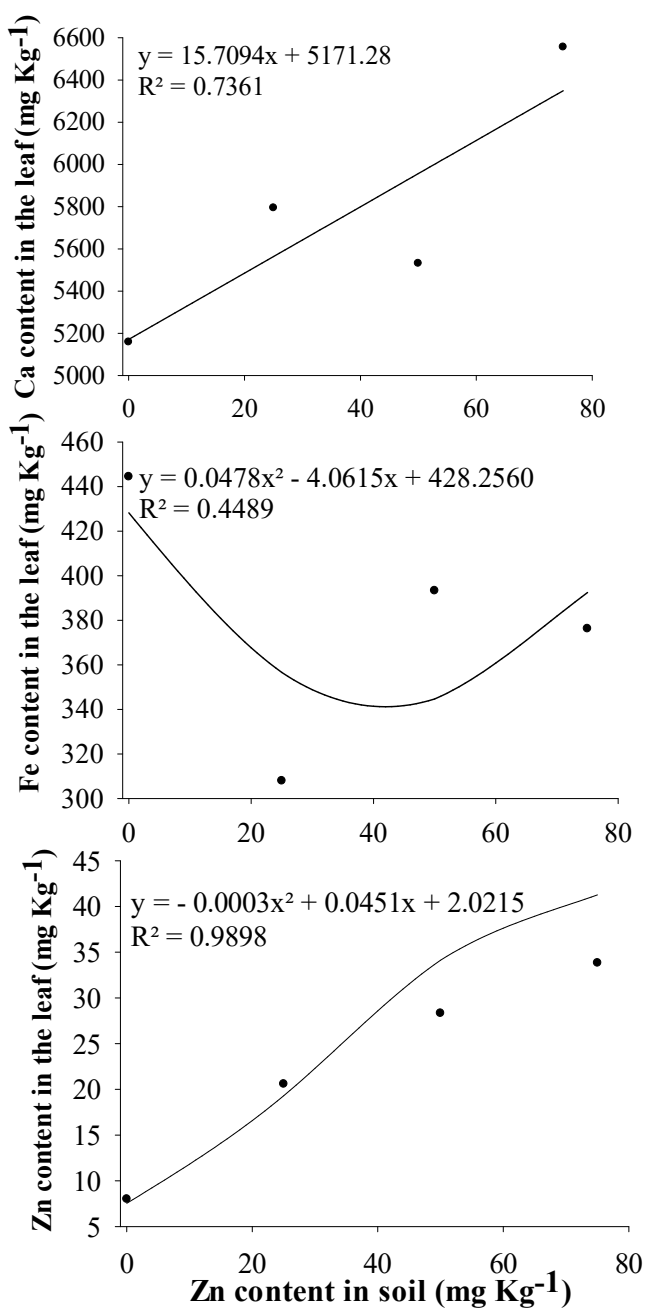

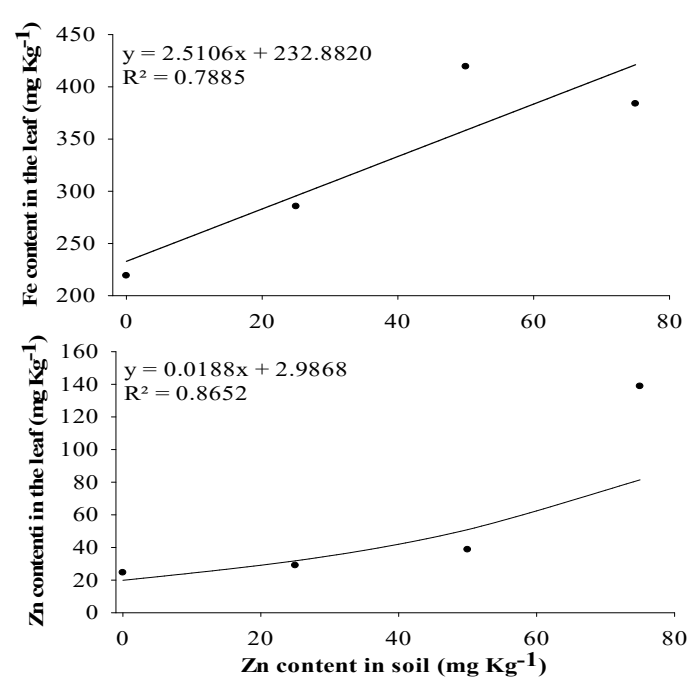

Fig. 5: Leaf contents of Iron and Zinc observed in Brachiaria humidicola submitted to increasing doses of $\mathrm{Zn}$.

Fig. 4: Calcium, Iron and Zinc contents in the aerial part of the species Panicum maximum Jacq. cv. Aruana grown in soil with increasing doses of $\mathrm{Zn}$.
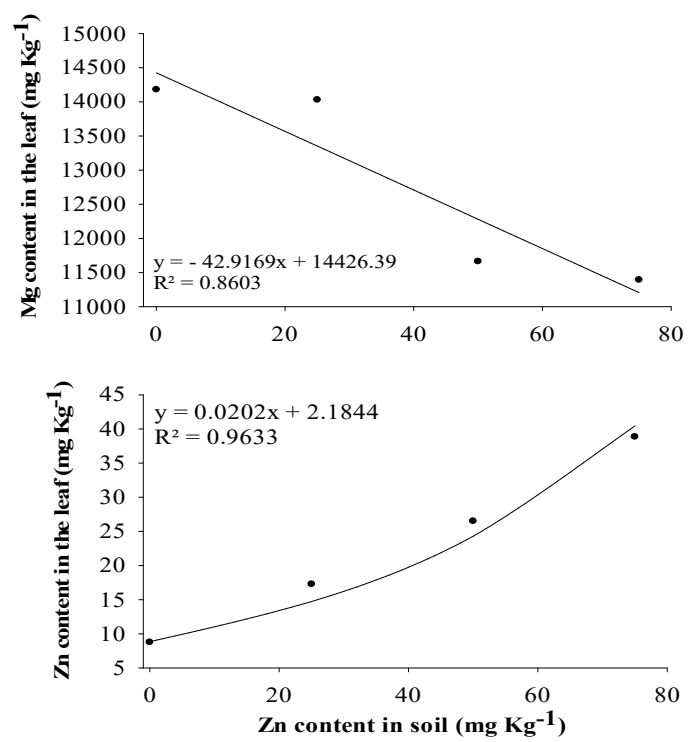

Fig. 6: Magnesium and Zinc contents found in the aerial part of Panicum maximum Jacq. cv. Tanzania, submitted to different doses of $\mathrm{Zn}$ in the soil. 


\section{Critical limit for Aruana, Tanzania and Humidicola}

The LC expresses the concentration of $\mathrm{Zn}$ applied to the soil, which reduces $10 \%$ of production, being important to assess productive losses and optimize fertilization (NARDIS et al., 2017). The critical limits observed for Aruana, Tanzania and Humidicola were 13.0; 9.1 and $29.1 \mathrm{mg} \mathrm{Kg}^{-1}$, respectively, as shown in Figure 7. Confirming the different levels of Zn sensitivity by forage species, which can be explained by the intrinsic characteristics between them.

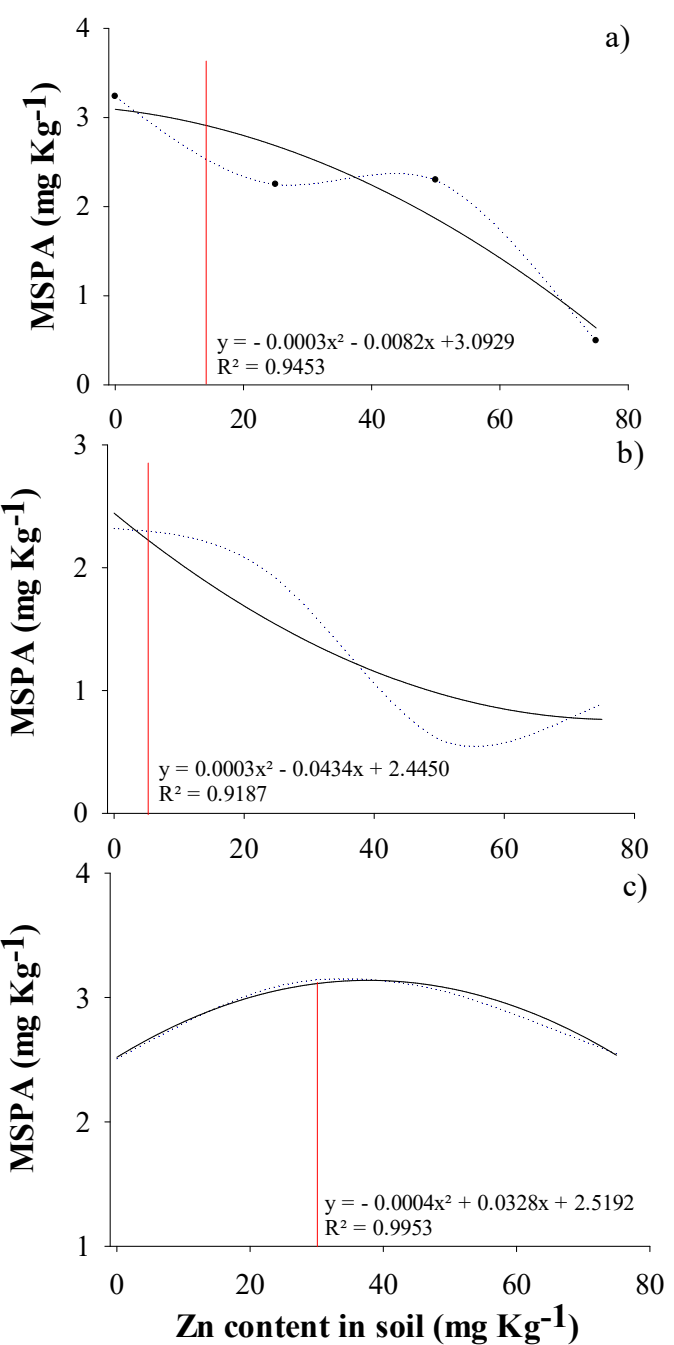

Fig. 7: Critical limit observed for Panicum maximum Jacq. cv. Aruana (a), Panicum maximum Jacq. cv. Tanzania (b) and Brachiaria humidicola $(\mathrm{c})$ exposed to increasing doses of $\mathrm{Zn}$ in the soil.

\section{DISCUSSION}

$\mathrm{Zn}$ acts as a cofactor, activating different hormones (auxin), necessary for plant growth and development (BEGUM et al., 2016), thus, the increase in MSPA yield with the increase in $\mathrm{Zn}$ doses for Pensacola may be associated with the function of enzymatic activation of metabolic processes (HERNANDES et al., 2009). While the reduction of MSPA observed in Aruana may indicate low tolerance of the species to the increase in the $\mathrm{Zn}$ content in the soil, since the reduction of the leaf area and consequent reduction of photosynthesis and decrease of production due to the triggered toxicity (CHERIF et al., 2010; ALEXANDRE et al., 2012). The decrease in MSPA with excess Zn consists of the difficulty of rising sap as a consequence of 
the accumulation of callose present in the xylem (PEDROSA et al., 2013). Nardis et al. (2017) evaluated the effects of increasing doses of $\mathrm{Zn}(0,100,300$ and 900 on the soil in Aruana, Tanzania, Marandu and Xaraes, verifying a reduction in MSPA for all grasses.

The inhibition of the absorption and translocation of $\mathrm{Mg}$ to the chloroplast triggers the reduction of the SPAD index, as a consequence of the decrease in the biosynthesis of photosynthetic pigments such as chlorophyll (a, b) as seen for Tanzania (TSONEV et al., 2012). Also, the reduction in the SPAD index for Aruana and Tanzania may be associated with the formation of buffers in the xylem, as a result of excess $\mathrm{Zn}$, making it difficult for the crude sap to rise, reducing the concentration of chlorophyll (a, b) (SILVA et al., 2010). For both situations there is a decline in the activity of photosystem II (PS II). The potential of PS II is compromised by reducing the transfer of electrons from the primary plastoquinone receptor ( $Q$ a) to the secondary plastoquinone receptor (Qb) on the PSII acceptor side (SHU et al., 2016). Thus, the use of electrons is reduced in primary processes, such as the production of NADPH in chloroplasts during biochemical $\mathrm{CO}_{2}$ fixation. With the reduction of NADPH availability, there is a decrease in chlorophyll synthesis by the enzyme divinyl chlorophyllide $\alpha$ 8-vinylreductase, which uses NADPH as a substrate (Silva et al. 2012). Still, the excess of Zn in the aerial part favours the production of reactive $\mathrm{O}_{2}$ species causing oxidative stress, since these substances are toxic to chloroplasts (SANTOS et al., 2009b).

\section{Nutrient Content in Species}

The quadratic and linear increase in Fe content in Aruana and Humidicola leaves respectively as a function of the increase in the $\mathrm{Zn}$ dose applied to the soil is due to the strategy mechanism II commanded by phytosiderophores, which are chelating agents and have Fe affinity (PUSCHENREITER et al., 2017). Plants exude phytosiderophores to the rhizosphere, which bind to $\mathrm{Fe}^{3+}$ and form a chelate complex ( $\mathrm{Fe}^{3+}-\mathrm{FS}$ ) by the action of the enzyme nicotianamine synthase (ZHAO et al., 2019). The absorption of this complex occurs through the plasma membrane with the aid of transporters from the Yellow Stripe family (YS) (ALEXANDRE et al., 2012; DAl et al., 2019), following the transpiration flow to the aerial part (NOZOYE et al., 2011; ARAUJO et al., 2020).

Solubilization of $\mathrm{Zn}$ by grasses is similar to strategy II for Fe, since phytosiderophores have affinity for other cations (WALTER et al., 2016). Still, the accumulation of Zn concentration in the roots favours the excess to be translocated to the aerial part (NARDIS et al., 2017). This behaviour was observed for Aruana, Humidicola and Tanzania. Leaf content varied among forage species, confirming that there are different levels of absorption between them. The maximum $\mathrm{Zn}$ content observed, at the dose of $75 \mathrm{mg} \mathrm{Kg}^{-1}$, was for Humidicola (138.79 $\mathrm{mg} \mathrm{kg}^{-1}$ ) and the lowest content found in Aruana $\left(33.82 \mathrm{mg} \mathrm{kg}^{-1}\right)$. Zn has moderate phytotoxicity, and when it is translocated to the aerial part, it occurs, through the biochemical mechanism of plants, storage of the element in vacuoles, chloroplasts and cell membranes (NARDIS et al., 2017).

It is important to note that the absorption mechanism shared by $\mathrm{Zn}$ and Fe results in competitiveness for complexation, affecting the bioavailability of the elements, as observed for Aruana and Humidicola (SCHENKEVELD et al., 2014). 
The differences in leaf content for $\mathrm{Zn}$ between species is explained by the distinct nutritional requirement, as well as the absorption efficiency depends on the amount of exudated phytosiderophores, being different between SPECIES (FLORA et al., 2010; OBURGER et al., 2014). And the lower Zn content in the leaf observed for Aruana can be attributed to the reduction in MSPA, since the extraction of $\mathrm{Zn}$ for the aerial part is mainly influenced by the MSPA variable (SHEORAN et al., 2010).

The reduction in Mg levels observed for Tanzania is attributed to inhibition triggered by $\mathrm{Zn}$. Both are bivalent cations, so they compete for the same bioactive sites. Mg is replaced by $\mathrm{Zn}$ in chlorophyll molecules, causing metabolic imbalance, such as altering the photosynthetic capacity of plants (ALBUQUERQUE et al., 2020).

\section{Critical limit for Aruana, Tanzania and Humidicola}

Aerial part $\mathrm{Zn}$ and dry matter production data were used to find the LC for the species Aruana, Tanzania and Humidicola, which was based on a $10 \%$ reduction in the production of these species (FAGERIA, 2000). Finding the critical $\mathrm{Zn}$ limit of these species is essential, as zinc can affect plant growth both when its content is lower and higher than the critical level, this is due to deficiency and/or toxicity problems, respectively (NOULAS et al., 2018).

The critical levels of nutrients in the leaf provide necessary information for the assessment of the nutritional status of a given crop, assisting with fertilization recommendations and/or soil nutritional corrections if necessary (LEITE et al., 2003).

Although there is no zinc deficiency in pastures, it is observed that the $\mathrm{Zn}$ content in plant tissue in many forages, tends to be lower than the minimum requirement for cattle (ALLOWAY, 2008), which is $30 \mathrm{mg}$ $\mathrm{kg}^{-1}$ of dry matter $\mathrm{Zn}$ for beef cattle (NRC, 1996). Thus, it is recommended that when the $\mathrm{Zn}$ levels are below $20 \mathrm{mg} \mathrm{kg}^{-1}$, an inorganic (or organic) fertilization is carried out through foliar applications or in the $\mathrm{Zn}$ soil (CHATZISTATHIS, 2014).

\section{CONCLUSIONS}

Pensacola showed responses to soil zinc doses, decreasing for leaf length and increasing for MSPA. The doses of zinc in the soil caused a decrease in MSPA for Aruana and the SPAD index for Aruana and Tanzania. Aruana showed an increase in Ca and $\mathrm{Zn}$ in the leaf when exposed to zinc doses in the soil. The species had different critical limits, Tanzania had the lowest LC and Humidicola the highest LC for zinc doses. Humidicola has potential to be cultivated in places where there is a lack of zinc in forages, since it presented a higher LC to this micronutrient and a higher concentration of zinc in the leaves.

\section{REFERENCES}

ALLOWAY, B. J.. Zinc in soils and crop nutrition. IZA and IFA, Brussels, Belgium and Paris, France. 2008.

ALEXANDRE, J. R.; OLIVEIRA, M. L. F.; SANTOS, T. C.;

CANTON, G. C.; CONCEIÇÃO, J. M.; EUTRÓPIO, F. J.; CRUZ, Z.
M. A.; DOBBSS, L. B.; RAMOS, A. C.. Zinco e ferro: de micronutrientes a contaminantes do solo. Natureza, v.10, n.1, p.23-28, 2012

ARAUJO, T. O.; ISAURE, M. P.; ALCHOUBASSI, G.; BIERLA, K.; 
SZPUNAR, J.; TRCERA, N.; CHAY, S.; ALCON, C.; SILVA, L. C.; CURIE, C.; MARI, C.. Paspalum urvillei and Setaria parviflora, two grasses naturally adapted to extreme iron-rich environments. Plant Physiol. Biochem, v.151, p.144-156, 2020. DOI: https://doi.org/10.1016/j.plaphy.2020.03.014

BEGUM, M. C.; ISLAM, M.; SARKAR, M. R.; AZAD, M. A. S.; HUDA, A. N; KABIR, A. H.. Auxin signaling is closely associated with $\mathrm{Zn}$-efficiency in rice (Oryza sativa L.). J. Plant Interact, v.11, n.1, p.124-129, 2016. DOI: https://doi.org/10.1080/17429145.2016.1220026

CHATZISTATHIS, T.. Micronutrient deficiency in soils and plants. Paris: Bentham Science Publishers, 2014.

CHERIF, J.; DERBEL, N.; NAKKACH, M.; VON BERGMANN, H.; JEMAL, F.; LAKDAR, Z. B.. Analysis of in vivo chlorophyll fluorescence spectra to monitor physiological state of tomato plants growing under zinc stress. J. Photochem. Photobiol, B, v.101, n.3, p.332-339, 2010. DOI: https://doi.org/10.1016/i.jphotobiol.2010.08.005

DAI, J.; QIU, W.; WANG, N.; WANG, T.; NAKANISHI, H.. From Leguminosae/Gramineae intercropping systems to see benefits of intercropping on iron nutrition. Front. Plant Sci, v.10, n.8, p.605, 2019. DOI:

https://doi.org/10.3389/fpls.2019.00605

FAGERIA, N. K.. Níveis adequados e tóxicos de zinco na produção de arroz, feijão, milho, soja e trigo em solo de cerrado. Rev. Bras. Eng. Agric., v.4, n.3, p.390-395, 2000. DOI: https://doi.org/10.1590/S1415-43662000000300014

FAQUIN, V.. Nutrição mineral de plantas. Lavras: UFLA/FAEPE, 2005.

FLORA, S. J.; PACHAURI, V.. Chelation in metal intoxication. Int. J. Environ. Res. Public Health, v.7, n.7, p.2745-2788, 2010. DOI: https://doi.org/10.3390/ijerph7072745

HERNANDES, A.; MELLO, P. R.; SOUZA, P. F.; MODA, L. R.; SANTOS, I. J. G.. Desenvolvimento e nutrição do CapimTanzânia em função da aplicação de zinco. AS, v.10, n.5, p.383-389, 2009. DOI:

http://dx.doi.org/10.5380/rsa.v10i5.15195

LEITE, U. T.; AQUINO, B. F.; ROCHA, R. N. C.; SILVA, J.. Níveis críticos foliares de boro, cobre, manganês e zinco em milho. Biosci. J., v.19, n.2, p.115-125, 2003.

MUNER, L. H. D.; RUIZ, H. A.; VENEGAS, V. H.; NEVES, J. C.; FREIRE, F. J.; FREIRE, M. B. G. S.. Disponibilidade de zinco para milho em resposta à localização de fósforo no solo. Rev. Bras. Eng. Agric. Ambiental, v.15, n.1, p.29-38, 2011. DOI: http://dx.doi.org/10.1590/S1415$\underline{43662011000100005}$

NARDIS, B. O.; SILVA, E. B.; GRAZZIOTTI, P. H.; ALLEONI, L. R.; MELO, L. C.; FARNEZI, M. M. M.. Availability and zinc accumulation in forage grasses grown in contaminated soil. Int. J. Phytorem, v.20, n.3, p.205-213, 2018. DOI: https://doi.org/10.1080/15226514.2017.1365347

NOULAS, C.; TZIOUVALEKAS, M.; KARYOTIS, T.. Zinc in soils, water and food crops. J. Trace Elem. Med. Biol., v.49, p.252260, 2018. DOI:

\section{https://doi.org/10.1016/j.jtemb.2018.02.009}

NOZOYE, T.; NAGASAKA, S.; KOBAYASHI, T.; TAKAHASHI, M.; SATO, Y.; SATO, Y.; UOZUMI, N.; NAKANISHI H.; NISHIZAWA, N. K.. Phytosiderophore efflux transporters are crucial for iron acquisition in graminaceous plants. J. Biol. Chem, v.286, n.7, p.5446-5454, 2011. DOI:

https://doi.org/10.1074/jbc.M110.180026

NRC. National Research Council. Nutrients Requeriments of Deef Cattle. Washington: Academy press, 1996.

OBURGER, E.; GRUBER, B.; SCHINDLEGGER, Y.; SCHENKEVELD, W. D.; HANN, S.; KRAEMER, S. M.; WENZEL, W. W. W.; PUSCHENREITER, M.. Root exudation of phytosiderophores from soil-grown wheat. New Phytol, v.203, n.4, p.1161-1174, 2014. DOI: https://doi.org/10.1111/nph.12868

OLIVEIRA, S. C. D.; COSTA, M. C. G.; CHAGAS, R. D. C. S.; FENILLI, T. A. B.; HEINRICHS, R.; CABRAL, C. P.; MALAVOLTA, E.. Resposta de duas cultivares de arroz a doses de zinco aplicado como oxissulfato. Pesqui. Agropecu. Bras, 38, n.3, p.387-396, 2003. DOI: https://doi.org/10.1590/S0100204X2003000300008

PEDROSA, A. M.; MARTINEZ, H. E. P.; CRUZ, C. D.; DAMATTA, F. M.; CLEMENTE, J. M.. Crescimento de cultivares de café em resposta a doses contrastantes de zinco. Coffee Science, v.8, n.3, p.295-305, 2013.

PRADO, R. M.; ROMUALDO, L. M.; ROZANE, D. E.; VIDAL, A. D. A.; MARCELO, A. V.. Method of zinc application in the nutrition and the production of dry matter of maize brs 1001. Biosci. J., v.24, n.1, p.67-74, 2008.

PUSCHENREITER, M.; GRUBER, B.; WENZEL, W. W.; SCHINDLEGGER, Y.; HANN, S.; SPANGL, B.; SCHENKEVELD, W. D. C.; KRAEMER, S. M.; OBURGER, E.. Phytosiderophoreinduced mobilization and uptake of $\mathrm{Cd}, \mathrm{Cu}, \mathrm{Fe}, \mathrm{Ni}, \mathrm{Pb}$ and $\mathrm{Zn}$ by wheat plants grown on metal-enriched soils. Environ. Exp. Bot, v.138, p.67-76, 2017. DOI: https://doi.org/10.1016/j.envexpbot.2017.03.011

SADEGHZADEH, B.. A review of zinc nutrition and plant breeding. J. Soil Sci. Plant Nutr, v.13, n.4, p.905-927, 2013. DOI: http://dx.doi.org/10.4067/S0718-95162013005000072

SANTOS, H. C.; FRAGA, V.S.; RAPOSO, R. W.; PEREIRA, W. E.. $\mathrm{Cu}$ e $\mathrm{Zn}$ na cultura do sorgo cultivado em três classes de solos: I. Crescimento vegetativo e produção. Rev. Bras. Eng. Agric. Ambiental, v.13, n.2, p.125-130, 2009a. DOI: https://doi.org/10.1590/S1415-43662009000200003

SANTOS, T. M.; FARIA, A. F. G.; AVALHÃES, C. C.; MELLO, P. R.. Produção de biomassa e nível crítico tóxico do capimxaraés em função da aplicação de zinco. Boletim de Indústria Animal, v.66, n.1, p.53-60, 2009b.

SCHENKEVELD, W. D. C.; SCHINDLEGGER, Y.; OBURGER, E.; PUSCHENREITER, M.; HANN, S.; KRAEMER, S. M..

Geochemical processes constraining iron uptake in strategy II Fe acquisition. Environ. Sci. Technol, v.48, n.21, p.1266212670, 2014. DOI: https://doi.org/10.1021/es5031728

TEIXEIRA, I. R.; BORÉM, A.; SILVA, A. G.; KIKUTI, H.. Fontes e doses de zinco no feijoeiro cultivado em diferentes épocas 
de semeadura. Acta Scientiarum. Agronomy, v.30, n.2 p.255-259, 2008. DOI:

https://doi.org/10.4025/actasciagron.v30i2.1739

TRIPATHI, D. K.; SINGH, S.; SINGH, S.; MISHRA, S.; CHAUHAN D. K.; DUBEY, N. K.. Micronutrients and their diverse role in agricultural crops: advances and future prospective. Acta Physiologiae Plantarum, v.37, n.7, p.1-14, 2015. DOI: https://doi.org/10.1007/s11738-015-1870-3

WALTER, M.; OBURGER, E.; SCHINDLEGGER, Y.; HANN, S.;
PUSCHENREITER, M.; KRAEMER, S. M.; SCHENKEVELD, W. D. C.. Retention of phytosiderophores by the soil solid phaseadsorption and desorption. Plant soil, v.404, n.1, p.85-97, 2016. DOI: https://doi.org/10.1007/s11104-016-2800-x

ZHAO, R. R.; QU, B. Y.; TONG, Y. P.; ZOU, C. Q.. Iron and zinc accumulation in winter wheat regulated by NICOTIANAMINE SYNTHASE responded to increasing nitrogen levels. J. Plant Nutr, v.42, n.14, p.1624-1636, 2019. DOI: https://doi.org/10.1080/01904167.2019.1630427

A CBPC - Companhia Brasileira de Produção Científica (CNPJ: 11.221.422/0001-03) detém os direitos materiais desta publicação. Os direitos referem-se à publicação do trabalho em qualquer parte do mundo, incluindo os direitos às renovações, expansões e disseminações da contribuição, bem como outros direitos subsidiários. Todos os trabalhos publicados eletronicamente poderão posteriormente ser publicados em coletâneas impressas sob coordenação da Sustenere Publishing, da Companhia Brasileira de Produção Científica e seus parceiros autorizados. Os (as) autores (as) preservam os direitos autorais, mas não têm permissão para a publicação da contribuição em outro meio, impresso ou digital, em português ou em tradução. 